\title{
Pengendalian Persediaan Bahan Baku Produk Active Speaker Menggunakan Algoritma Wagner Within di PT Hartono Istana Teknologi
}

\author{
Raw Material Inventory of Active Speaker Product \\ using Wagner Within Algorithm at PT Hartono Istana Teknologi
}

\author{
Auryn Thomas, Kartika Suhada \\ Program Studi Teknik Industri Universitas Kristen Maranatha \\ E-mail:aurynthomas@gmail.com, kartika.suhada@eng.maranatha.edu
}

\begin{abstract}
Abstrak
PT Hartono Istana Teknologi adalah perusahaan yang bergerak dalam bidang pembuatan produk elektronik, diantaranya: TV, DVD, mobile phone, tablet PC, portable audio dan active speaker. Saat ini perusahaan mengalami permasalahan penumpukan bahan baku produk active speaker. Hal ini menunjukkan kurang tepatnya metode pengendalian persediaan yang diterapkan. Selama ini Bagian PPIC telah memperhitungkan kebergantungan kebutuhan antar bahan baku untuk pembuatan produk jadi dan melakukan pemesanan bahan baku ke supplier tiap 4 hingga 5 minggu sekali, dimana periode tersebut ditetapkan berdasarkan estimasi yang belum mempertimbangkan besar elemen biaya pengendalian persediaan. Oleh karena itu dalam penelitian ini akan diusulkan pengendalian persediaan yang akan meminimasi total biaya pengendalian persediaan yang timbul.

Dalam penelitian ini yang diamati adalah produk active speaker tipe PS-PASO9(B)59, karena memiliki penjualan tertinggi. Langkah awal yang dilakukan menghitung elemen biaya pengendalian persediaan, meliputi: biaya pesan, biaya simpan dan biaya setup. Selanjutnya dilakukan perhitungan pengendalian persediaan dengan teknik lotting mengikuti kebijakan perusahaan dan teknik lotting Wagner Within yang merupakan usulan. Perhitungan MRP menggunakan bantuan program WinQSB versi2.0.

Berdasarkan hasil perhitungan diketahui bahwa penerapan teknik lot sizing usulan menghasilkan penurunan total biaya pengendalian persediaan dari Rp 111,033,881.91 menjadi Rp 147,617,045.19. Dengan demikian terjadi penghematan sebesar Rp 36,583,163.28 atau $25 \%$.
\end{abstract}

Kata kunci: Pengendalian Persediaan, Bahan Baku, Wagner Whitin

\begin{abstract}
PT Hartono Istana Teknologi is engaged in manufacturing of electronic products, including: TVs, DVDs, mobile phones, tablet PCs, portable audio and active speakers. Nowadays the company is running into problems with the accumulation of active speaker raw material. This matter shows that inventory control method applied is less precise. All this time, the PPIC has taken into account the dependency of the needs between raw materials for the manufacture of finished products and ordering raw materials from suppliers every four to five weeks, where the period is determined based on estimates that do not take into account the size of the inventory control cost. Therefore, this research will propose inventory control which will minimize total inventory control costs incurred.

In this study, the active speaker products type PS-PASO9 (B) 59 will be observed, for having the highest sales. The initial step taken is to calculate the cost of inventory control elements, including: ordering costs, storage costs, and setup costs. Further, inventory control is calculated using the lotting technique following company policy and the Wagner Within lotting technique which is the proposal. MRP calculation is using the assistance of WinQSB version 2.0.

Build upon the calculation outcome that the application of the proposed lot sizing technique resulted a decrease in total inventory control costs from Rp111,033,881.91 to Rp147,617,045.19. Thus a saving of Rp36,583,163.28 or $25 \%$.
\end{abstract}

Keyword: Inventory Control, Raw Material, Wagner Whitin 


\section{Pendahuluan}

Saat ini industri manufaktur jenis elektronik berkembang dengan pesat seiring dengan kemajuan teknologi. Hal ini menyebabkan timbulnya persaingan antar perusahaan sejenis yang semakin ketat. Oleh karena itu perusahaan harus dapat memenuhi permintaan konsumen dengan tepat waktu. Salah satu faktor pendukung adalah ketersediaan bahan baku yang mencukupi. Persediaan bahan baku perlu dikendalikan dengan baik, karena apabila berlebihan akan menimbulkan biaya simpan yang tinggi dan sebaliknya apabila kekurangan akan menimbulkan terhentinya kegiatan proses produksi. Kedua hal tersebut tentu saja merugikan pihak perusahaan.

PT Hartono Istana Teknologi (HIT) merupakan perusahaan yang bergerak dalam bidang industri manufaktur produk elektronik dengan brand Polytron. Produk elektronik yang diproduksi beraneka ragam, diantaranya: TV, DVD, mobile phone, tablet $\mathrm{PC}$, portable audio dan active speaker. Seluruh produk yang diproduksi oleh PT HIT merupakan produk rakitan, sehingga bahan baku yang dibutuhkan dibeli langsung dari supplier, baik dalam maupun luar negeri. Permasalahan yang terjadi adalah penumpukan bahan baku active speaker di gudang dikarenakan kurang tepatnya metode pengendalian persediaan yang diterapkan saat ini. Selama ini Bagian PPIC yang menangani pengendalian persediaan telah mempertimbangkan faktor kebergantungan besar kebutuhan bahan baku terhadap jumlah produk jadi yang akan diproduksi, namun melakukan pemesanan bahan baku ke supplier dengan periode pemesanan yang cukup panjang, yaitu tiap 4 hingga 5 minggu sekali, dimana periode waktu pemesanan tersebut ditetapkan berdasarkan estimasi. Hal tersebut menyebabkan rata-rata penyimpanan barang di gudang cukup banyak, sehingga ongkos simpan yang timbul cukup besar dan akibatnya total biaya pengendalian persediaan menjadi cukup besar pula. Oleh karena itu penelitian ini mengusulkan pengendalian persediaan yang mempertimbangkan besar elemen biaya pengendalian persediaan agar total biaya pengendalian persediaan yang timbul dapat diminimasi.

Batasan masalah yang digunakan meliputi :

1. Tipe active speaker yang diteliti PS-PAS09(B)59, karena tipe ini memiliki penjualan tertinggi dibandingkan tipe lainnya.

2. Data Jadwal Induk Produksi (JIP) yang digunakan adalah JIP bulan Juli 2018 - Desember 2018.

3. Elemen biaya yang dihitung elemen biaya yang berpengaruh, yaitu biaya pemesanan, biaya setup dan biaya penyimpanan bahan baku.

Asumsi yang digunakan pada penelitian ini adalah:

1. Tidak terjadi perubahan Jadwal Induk Produksi (JIP) selama periode pengamatan.

2. 1 tahun $=48$ minggu.

Tujuan dari penelitian ini adalah sebagai berikut:

1. Mengidentifikasi kekurangan metode pengendalian persediaan bahan baku yang diterapkan perusahaan saat ini.

2. Mengusulkan metode pengendalian persediaan bahan baku yang sebaiknya diterapkan perusahaan.

3. Mengemukakan manfaat yang dapat diperoleh perusahaan dengan menerapkan metode pengendalian persediaan usulan.

\section{Tinjauan Pustaka}

\subsection{Definisi Persediaan}

Persediaan adalah komponen material, atau produk jadi yang tersedia di tangan, menunggu untuk digunakan atau dijual. (Baroto, 2002). Persediaan dapat berupa bahan mentah, bahan pembantu, bahan dalam proses, barang jadi, ataupun suku cadang. Hal tersebut dapat dikatakan persediaan hanyalah suatu sumber dana menganggur karena sebelum persediaan digunakan berarti dana terikat di dalamnya tidak dapat digunakan untuk keperluan lain (Rusdiana, 2014). 


\subsection{Jenis-Jenis Persediaan}

Dalam sistem manufaktur, item persedian dapat dikelompokkan dalam lima bentuk, sebagai berikut: (Baroto,2002)

1. Bahan baku (raw material), yaitu barang-barang yang berwujud atau bahan-bahan mentah lainnya yang diperoleh dari sumber-sumber alam, atau dibeli dari pemasok.

2. Komponen, yaitu barang - barang yang terdiri atas bagian-bagian (parts) yang diperoleh dari perusahaan lain atau hasil produk sendiri untuk digunakan dalam pembuatan barang jadi atau barang setengah jadi.

3. Barang setengah jadi (work in process) yaitu barang-barang yang dari tiap perakitan yang telah memiliki bentuk lebih kompleks daripada komponen,namun masih perlu proses lebih lanjut untuk menjadi barang jadi.

4. Barang jadi (finished good) adalah barang - barang yang telah selesai diproses dan siap untuk didistribusikan ke konsumen.

5. Bahan pembantu adalah barang - barang yang diperlukan dalam proses pembuatan atau perakitan barang, namun bukan komponen barang jadi. Termasuk bahan penolong adalah bahan bakar adalah bahan bakar, pelumas, listrik dan lain-lain.

\subsection{Sistem Persediaan}

Sistem persediaan adalah suatu mekanisme mengenai bagaimana menegelola masukan - masukan yang sehubungan dengan persediaan menjadi output, dimana untuk diperlukan output memenuhi standar tertentu.

Variabel keputusan dalam pengendalian persediaan diklasifikasikan sebagai variabel kualitatif dan variabel kuantitatif. Secara variabel kuantitatif pada pengendalian persediaan sebagai berikut: (Baroto,2002)

1. Berapa banyak jumlah barang yang akan dipesan atau dibuat.

2. Kapan pemesanan atau pembuatan harus dilakukan.

3. Berapa jumlah persediaan pengaman.

4. Bagaimana mengendalikan persediaan

Tujuan dari sistem pengendalian persediaan adalah menemukan solusi optimal terhadap seluruh yang terkait dengan persediaan. Tujuan umum perusahaan untuk optimalisasi pengendalian persediaan diukur dengan keuntungan maksimum yang dicapai.

\subsection{Biaya Dalam Sistem Persediaan}

Dalam pembuatan setiap keputusan, maka terdapat kategori biaya persediaan yang harus dipertimbangkan: (Nur Bahagia, 2006)

1. Biaya pembelian (Purchasing cost) adalah biaya yang dikeluarkan untuk membeli barang sebagi persediaan.

2. Biaya pengadaan adalah biaya yang harus dikeluarkan untuk setiap proses pengadaan barang. Biaya pengadaan dibedakan atas dua jenis yaitu biaya pesan jika barang dibeli dan biaya persiapan jika barang dibuat sendiri. Biaya pesan adalah semua pengeluaran yang ditimbulkan untuk mendatangkan barang dari luar. Biaya persiapan adalah biaya yang ditimbulkan untuk persiapan produksi barang.

3. Biaya simpan (Holding cost) adalah biaya untuk menyimpan persediaan yang terdapat di dalam gudang. Biaya yang termasuk sebagai biaya simpan adalah biaya memiliki persediaan, biaya gudang, biaya kerusakan atau penyusutan, biaya kadaluarsa, biaya asuransi, biaya administrasi, dan biaya lain-lain.

4. Biaya kehabisan dan kekurangan bahan (shortage cost) biaya ini timbul apabila persediaan tidak mecukupi permintaan. Penentuan besar biaya kekurangan persediaan dapat diukur berdasarkan: kuantitas yang tidak terpenuhi, waktu pemenuhan, biaya pengadaan darurat.

5. Biaya sistematik adalah biaya investasi untuk membangun sistem persediaan. Biaya ini meliputi biaya perancangan, perencanaan dan instalasi sistem persediaan serta ongkosongkos untuk mengadakan peralatan serta melatih tenaga untuk menggunakan sistem. 


\subsection{MRP}

Pada MRP terdapat tiga akronim yang berbeda tetapi dalam konteks yang berhubungan yaitu:

(Santoso dan Heryanto, 2017)

1. MRP I (Material Requirement Planning)

2. Closed loop MRP

3. MRP II (Manufacturing Resource Planning)

\subsection{Pengertian MRP I}

MRP/MRP I merupakan sekumpulan teknik yang digunakan untuk merencanakan produksi atau pengadaan dari subassemblies, komponen, atau bahan baku atau raw material yang dibutuhkan untuk Jadwal Induk Produksi (JIP). Dasar dari MRP adalah mendapatkan material yang tepat pada tempat yang tepat dan pada waktu yang tepat (to get the right materials to the right place at the right time) (Santoso dan Heryanto, 2017).

MRP adalah suatu sistem perencanaan dan penjadwalan kebutuhan material untuk produksi yang memerlukan beberapa tahapan proses atau dengan kata lain adalah suatu rencana produksi untuk sejumlah produk jadi yang diterjemahkan ke komponen yang dibutuhkan dengan menggunakan waktu tenggang sehingga dapat ditentukan kapan dan berapa banyak yang dipesan untuk masingmasing komponen suatu produk yang akan dibuat.(Rangkuti, 2004)

\subsection{Konsep MRP}

Konsep dasar dari MRP adalah untuk meyediakan material pada jumlah yang tepat, tempat yang tepat dan waktu yang tepat (to get the right materials to the right place at the right time). (Fogarty,1991). MRP digunakan untuk permintaan/demand yang bersiafat dependent atau tem-item yang merupakan kompen produk akhir. Dependent demand adalah permintaan yang bergantung dari permintaan item lainnya. (Sheikh, 2002).

\subsection{Tujuan MRP}

Secara umum, sistem MRP untuk mencapai tujuan antara lain: (Kusuma, 2001)

1. Meminimalkan persediaan

MRP menentukan berapa banyak dan kapan suatu komponen diperlukan disesuaikan dengan jadwal induk produksi.

2. Mengurangi resiko

MRP mengidentifikasi banyaknya bahan dan komponen yang diperlukan baik dari segi jumlah dan waktu sehingga hal tersebut dapat mengurangi resiko keterlambatan produksi atau pengiriman.

3. Jadwal produksi terpenuhi

Jadwal produksi diharapkan dapat terpenuhi sesuai dengan rencana, sehingga komitmen terhadap pengirim barang dapat dilakukan secara nyata.

4. Meningkatkan efisiensi

MRP mendorong peningkatan efisieni karena jumlah persediaan, waktu produksi, dan waktu pengiriman barang dapat direncanakan lebih baik sesuai dengan jadwal induk produksi.

\subsection{Input MRP}

Terdapat beberapa input proses MRP yang utama agar sistem MRP dapat dijalankan dengan baik. Input MRP terdapat tiga jenis, yaitu: (Kusuma, 2001)

1. Jadwal Induk Produksi (JIP) atau Master Production Schedule (MPS) adalah suatu rencana rinci tentang jumlah barang yang akan diproduksi pada beberapa satuan waktu dalam horisontal perencanaan.

2. Struktur Produk (Bill OF Material) berisi informasi mengenai material, komponen, sub assembly, yang diperlukan untuk membuat produk jadi dan hubungan antar komponen dalam suatu perakitan. Bill of Material adalah daftar kuantitas komponen, kandungan, dan kebutuhan bahan untuk membuat suatu unit produk atau parent assembly 
3. Catatan status persediaan

Status persediaan menggambarkan keadaan setiap komponen atau bahan yang terdapat dalam sistem persediaan. Status persediaan meliputi: (Santoso dan Heryanto , 2017)

a. Persediaan yang tersedia (inventory on hand/available inventory yaitu persediaan apa saja (persediaan sub assemblies, komponen - komponen, material) yang disimpan atau tersedia dan siap di dalam gudang untuk digunakan.

b. Jadwal penerimaan (inventory on order), total dari seluruh perkiraan penerimaan dimana pembelian atau produksi telah dilakukan.

c. Waktu ancang (lead time) adalah jangka waktu atau selang waktu antara permintaan untuk pembelian atau produksi dan penerimaan dari barang.

d. Waktu ancang pengaman (safety lead time) adalah jangka waktu atau selang waktu antara permintaan untuk melindungi atau mengantisipasi fluktuasi dari lead time produksi atau pembelian.

e. Ukuran lot (lot sizing), suatu teknik untuk menentukan jumlah dari item yang harus diproduksi oleh pabrik atau dipesan dari vendor atau pabrik.

\subsection{Output MRP}

Setelah input MRP dilengkapi, maka akan dihasilkan output, yaitu pembelian dan perencanaan produksi atau purchase and production plan, seperti terlihat Gambar 1.

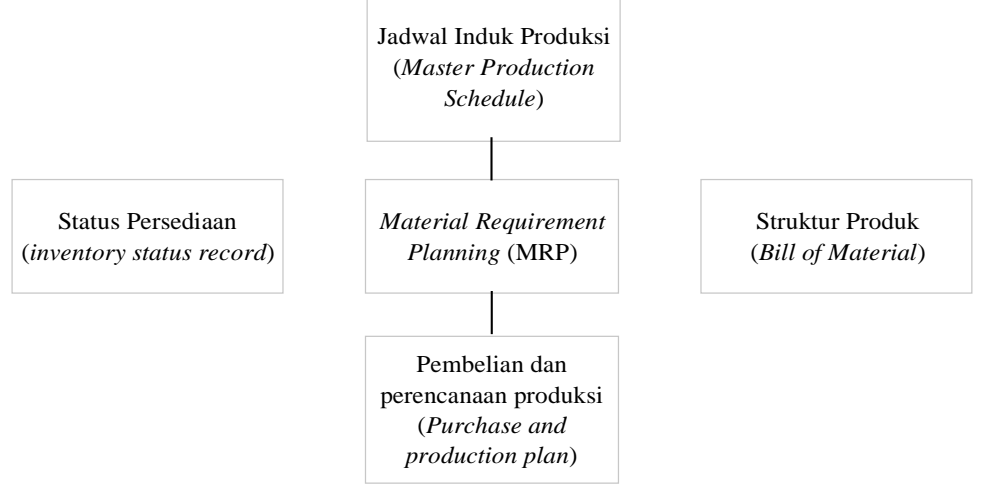

Sumber: Fogarty, 1991

Gambar 1. Input dan Output MRP

\subsection{Proses MRP}

Proses MRP terdiri dari empat tahapan, yaitu: (Santoso dan Heryanto, 2017)

1. Netting merupakan proses perhitungan untuk menghitungkan kebutuhan bersih.

Net requirements $=\max \{0 ; \mathrm{Dt}-\mathrm{lt}-\mathrm{Qt}\}$

Jika diinginkan adanya safety stock maka:

Net requirements $=\max \{0 ; \mathrm{Dt}+\mathrm{SS}-\mathrm{lt}-\mathrm{Qt}\}$

Dimana:

Dt $\quad=$ kebutuhan kotor pada periode $\mathrm{t}$

Lt = persediaan yang ada di awal periode $\mathrm{t}$

$=$ persediana yang ada di akhir periode $\mathrm{t}-1$

Qt $\quad=$ jadwal penerimaan di periode $\mathrm{t}$

SS $\quad=$ safety stock

2. Lot Sizing merupakan proses untuk menentukan kuantitas pesanan (order quantity) yang optimal untuk masing-masing item produk berdasarkan hasil perhitungan kebutuhan bersih.

3. Offsetting merupakan proses untuk menentukan kapan pemesanan (order) yang tepat guna untuk melakukan rencana pemesanan dalam upaya memenuhi tingkat kebutuhan bersih ke lantai produksi maupun ke vendor.

4. Exploding merupakan proses perhitungan kebutuhan kotor untuk tingkat item komponen yang lebih awal. 


\subsection{Teknik Lotting Fix Periode Requirement}

Fixed Period Requirement adalah suatu teknik penentuan ukuran lot yang didasarkan pada waktu tertentu. Metode FPR ini selang waktu antar pemesanan dibuat tetap dengan ukuran lot sesuai pada kebutuhan bersih.

\subsection{Teknik Lotting Wagner Whitin (WW)}

Merupakan teknik yang paling kompleks dalam perhitungan. Secara teoritis teknik lot sizing wagner whitin adalah teknik yang mampu memberikan solusi optimal dalam masalah penentuan ukuran pemesanan deterministic dynamic. Teknik ini merupakan pendekatan pemrograman dinamis yang mana dapat digunakan untuk menentukan kebijakan minimum cost yang dapat dikontrol. (Tersine, 1994)

Perhitungan dengan teknik ini akan mendapatkan solusi optimal yang memuaskan karena penghambat dalam perhitungan dapat ditekan dengan mengacu pada dua buah sifat kunci, yaitu:

1. Bahan yang dibutuhkan datang apabila tingkat persediaan nol

2. Seberapa jauh limit teratas untuk pemesanan jumlah kebutuhan $D(j)$ sebelum periode $j$. Pada akhirnya dapat terlihat bahwa lebih mahal ongkos pengadaan hanya untuk kebutuhan periode $\mathrm{j}$, daripada ongkos pengadaan dengan memesan kebutuhsn untuk beberapa periode sekaligus.

Untuk menentukan kebijakan biaya yang minimum dengan menyederhanakan perhitungan melauli tiga tahapan sebagai berikut:

1. Menghitung total biaya variabel untuk semua alternatif pemesanan yang mungkin terjadi pada $\mathrm{N}$ periode. Total biaya variabel meliputi biaya pesan dan biaya simpan. Zce sebagai total biaya variabel di dalam periode c melalui e dalam penempatan suatu pesanan di dalam periode $\mathrm{c}$ untuk memenuhi kebutuhan dalam periode c sampai e.

Zce $=\mathrm{C}+\mathrm{HP}$ untuk $1 \leq \mathrm{c} \leq \mathrm{e} \leq \mathrm{N}$

Keterangan:

$\mathrm{C}=$ biaya pemesanan setiap pesanan

$\mathrm{H}=$ biaya simpan setiap periode

$\mathrm{P}=$ pembelian unit untuk pemenuhan kebutuhan

2. Menentukan fe sebagai biaya yang minimum sampai periode e, tingkat persediaan pada akhir periode e adalah 0 . Algoritma mulai dengan $\mathrm{f} 0=$ dsn kalkulasi f1,f2. $\mathrm{fN}$ di dalam pesanan tersebut. Kemudian fe dihitung dengan menggunakan rumusan:

$\mathrm{fe}=\operatorname{Min}($ Zce + fe-1) $\quad$ untuk $\mathrm{c}=1,2, \ldots, \mathrm{e}$

untuk masing-masing periode dengan membandingkan semua kombinasi alternatif pemesanan dan pengganti fe. Dipilih yang terbaik pada saat fe yaitu ketika kebutuhan untuk periode samapi e terpenuhi. Nilai $\mathrm{fN}$ adalah ongkos pesanan terjadwal yang optimal.

3. Untuk menerjemahkan solusi optimal (fN) ditentukan dengan algoritma untuk kuantitas pemesanan dengan:

$\mathrm{fN}=\mathrm{Zwn}+\mathrm{fw}-1$

Pemesanan terakhir terjadi pada periode $\mathrm{w}$ dan cukup untuk memenuhi permintaan selama periode $w$ dalam $\mathrm{N}$.

$\mathrm{fw}-1=\mathrm{Zv} \mathrm{w}-1+\mathrm{fv}-1$

Pemesanan terlebih dahulu didasarkan pada pemesanan terakhir yang terjadi pada periode $\mathrm{v}$ dan cukup untuk memenuhi permintaan dalam periode $\mathrm{v}$ dalam $\mathrm{w}-1$

$\mathrm{fu}-1=\mathrm{Z} 1 \mathrm{u}-1+\mathrm{f0}$

Pemesanan pertama terjadi pada periode 1 dan cukup untuk memenuhi permintaan selama periode 1 dalam $\mathrm{u}-1$.

\subsection{Penyesuaian Ukuran Lot}

Dalam jumlah rencana pembelian yang ditentukan dengan teknik ukuran lot sesuai dengan pertimbangan dalam praktek. Penyesuaian secara umum dapat berupa: (Sheiks, 2002)

1. Minimum dan maksimum

Jumlah minimum berarti jumlah pemesanan yang paling minimum yang diperbolehkan 
oleh supplier. sedangkan jumlah maksimum biasanya ditentukan oleh kebijakan manajemen atau keterbatasan besarnya ukuran gudang bahan baku.

2. Scrap allowance

Kuantitas yang bertambah dalam perhitungan ukuran lot sebagai kompensasi untuk mengantisipasi scrap atau kerusakan dalam proses.

3. Multiples

Pihak supplier mungkin hanya menjual dalam satuan lusin atau gross. Ukran kemasan atau pemotongan bahan baku dari ukuran lot, mengharuskan pemesanan bahan baku dalam bentuk kelipatan.

4. Raw material cutting factor

Merupakan pemotongan bahan mentah dan kerugian akibat perhitungan ukuran lot, maka untuk meminimasi kerugian tersebut perlu dilakukan penyesuaian.

\section{Pembahasan}

Bagan pengolahan data ditunjukkan pada Gambar 2:

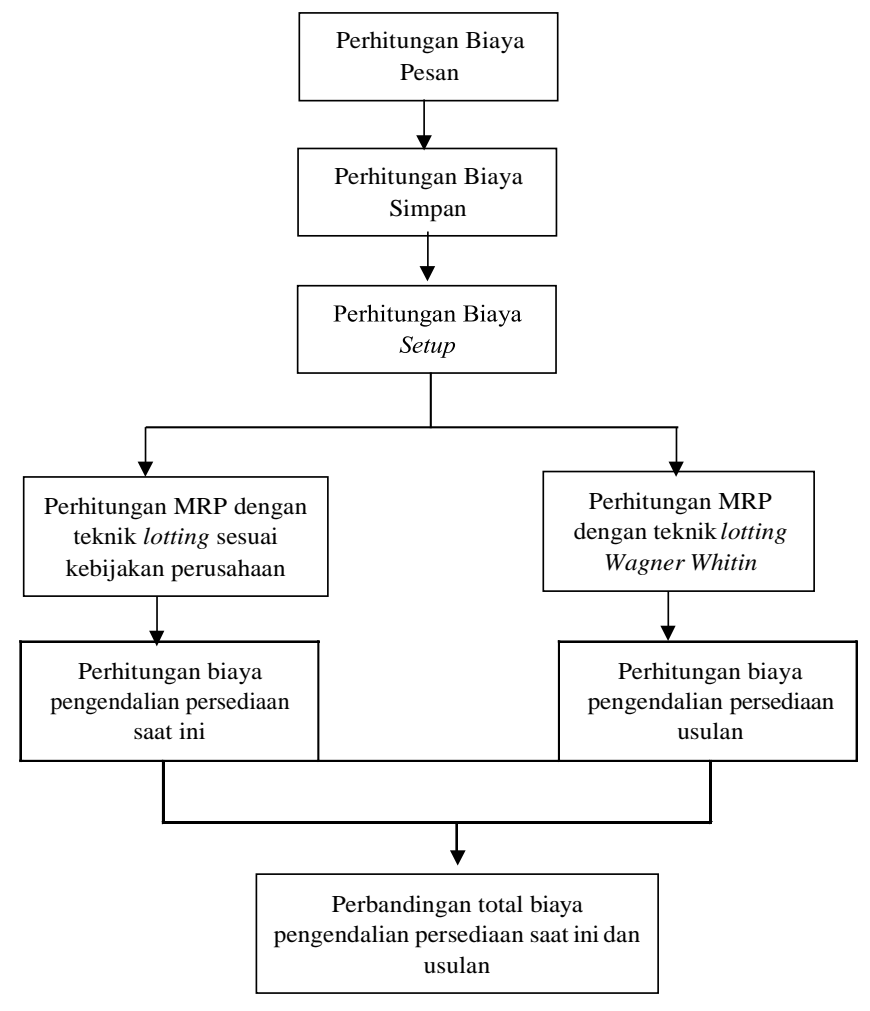

Gambar 2. Bagan Pengolahan Data

\subsection{Perhitungan Biaya}

\subsubsection{Biaya Pesan}

Biaya pesan merupakan biaya yang dikeluarkan untuk melakukan pembelian material atau komponen yang dari supplier. Elemen-elemen biaya yang termasuk biaya pesan adalah biaya telpon, biaya administrasi, biaya transfer, biaya ATK. Total biaya pesan yang dibutuhkan untuk supplier dalam kota, luar kota dan luar negeri satu kali pesan ditunjukkan dalam Tabel 1. 
PENGENDALIAN PERSEDIAAN (Auryn Thomas, dkk.)

Tabel 1. Perhitungan Total Biaya Pesan/kalipesan

\begin{tabular}{|c|lr|lr|lr|}
\hline Jenis & \multicolumn{2}{|c|}{$\begin{array}{c}\text { Biaya pesan } \\
\text { lokal }\end{array}$} & \multicolumn{2}{c|}{$\begin{array}{c}\text { Biaya pesan } \\
\text { interlokal }\end{array}$} & \multicolumn{2}{c|}{$\begin{array}{c}\text { Biaya pesan luar } \\
\text { negeri }\end{array}$} \\
\hline Biaya Telepon & $\mathrm{Rp}$ & 1,500 & $\mathrm{Rp}$ & 7,000 & $\mathrm{Rp}$ & 25,000 \\
\hline $\begin{array}{c}\text { Biaya data / } \\
\text { 20KB }\end{array}$ & $\mathrm{Rp}$ & 120 & $\mathrm{Rp}$ & 120 & $\mathrm{Rp}$ & 120 \\
\hline $\begin{array}{c}\text { Biaya } \\
\text { Administrasi }\end{array}$ & $\mathrm{Rp}$ & 47,396 & $\mathrm{Rp}$ & 47,396 & $\mathrm{Rp}$ & 47,396 \\
\hline Biaya Transfer & $\mathrm{Rp}$ & 6,500 & $\mathrm{Rp}$ & 6,500 & $\mathrm{Rp}$ & 35,000 \\
\hline Biaya ATK & $\mathrm{Rp}$ & 3,000 & $\mathrm{Rp}$ & 3,000 & $\mathrm{Rp}$ & 3,000 \\
\hline Total & $\mathrm{Rp}$ & 58,516 & $\mathrm{Rp}$ & 64,016 & $\mathrm{Rp}$ & 110,516 \\
\hline
\end{tabular}

\subsubsection{Biaya Simpan}

Biaya simpan merupakan biaya yang dikeluarkan oleh perusahaan akibat melakukan penyimpanan bahan baku dan komponen di gudang. Elemen biaya simpan terdiri dari biaya modal, biaya depresiasi, biaya asuransi, biaya PBB, biaya pekerja gudang, biaya listrik. Perhitungan persentase biaya simpan ditunjukkan dalam Tabel 2, sedangkan perhitungan besar biaya simpan untuk bahan baku dan barang jadi berturut-turut diperlihatkan dalam Tabel 3 dan Tabel 4.

Tabel 2. Rincian Persentase Biaya Simpan

\begin{tabular}{|l|c|}
\hline \multicolumn{1}{|c|}{ Biaya } & $\begin{array}{c}\text { Persentase biaya } \\
\text { simpan/tahun }\end{array}$ \\
\hline Biaya modal & $7.00 \%$ \\
\hline Biaya depresiasi & $0.085 \%$ \\
\hline Biaya asuransi & $0.0169 \%$ \\
\hline Biaya PBB & $0.0058 \%$ \\
\hline Biaya pekerja gudang & $7.152 \%$ \\
\hline Biaya Listrik & $0.0175 \%$ \\
\hline Total & $14.277 \%$ \\
\hline
\end{tabular}

Tabel 3. Perhitungan Biaya Simpan Bahan Baku

\begin{tabular}{|c|c|c|c|c|c|c|c|c|c|}
\hline No & Row Labels & Nama Material / Komponen & $\begin{array}{l}\text { Persentase } \\
\text { Biaya }\end{array}$ & $\begin{array}{l}\text { Hars } \\
\text { satu }\end{array}$ & & & $\begin{array}{l}\text { impan } \\
\text { tan } \\
\text { tahun }\end{array}$ & & $\begin{array}{l}\text { mpan } \\
\text { in } \\
\text { inggu } \\
\end{array}$ \\
\hline 1 & EC-134681-DAA00 & REFLECTOR FOR TWEETER GGB & $14.277 \%$ & $\mathrm{Rp}$ & 985 & $\mathrm{Rp}$ & 140.56 & $\mathrm{Rp}$ & 2.93 \\
\hline 2 & QS-P86314-H00 & $\begin{array}{c}\text { LBL PESAWAT PAS59(BUM) } \\
\text { BACKCOVER AUD QR }\end{array}$ & $14.277 \%$ & $\mathrm{Rp}$ & 46 & $\mathrm{Rp}$ & 6.55 & $\mathrm{Rp}$ & 0.1 \\
\hline 3 & EG-030104-BZB & $\begin{array}{l}\text { P-TITE SCREW MC PTZ } \\
\text { 3X10W/WASHER DIA } 10\end{array}$ & $14.277 \%$ & $\mathrm{Rp}$ & 91 & $\mathrm{Rp}$ & 12.96 & $\mathrm{Rp}$ & 0.2 \\
\hline 4 & QS-P86313-H00 & $\begin{array}{c}\text { LBL KARTON_BESAR PAS59(BUM) } \\
\text { ALL_2SISI_QR } \\
\end{array}$ & $14.277 \%$ & $\mathrm{Rp}$ & 137 & $\mathrm{Rp}$ & 19.52 & $\mathrm{Rp}$ & 0.41 \\
\hline 5 & GN-184470-HKA00 & $\begin{array}{l}\text { STICKER IC FLASH ROM } \\
\text { GGHBLANK }(1 \mathrm{LBR}=20 \mathrm{PC}\end{array}$ & $14.277 \%$ & $\mathrm{Rp}$ & 8 & $\mathrm{Rp}$ & 1.07 & $\mathrm{Rp}$ & 0.02 \\
\hline 6 & EG-030120-PVA & P-TITE SCREW ZK PTV 3X12 & $14.277 \%$ & $\mathrm{Rp}$ & 99 & $\mathrm{Rp}$ & 14.13 & $\mathrm{Rp}$ & 0.2 \\
\hline 7 & GN-000001-00A & STICKER HOLOGRAM & $14.277 \%$ & $\mathrm{Rp}$ & 212 & $\mathrm{Rp}$ & 30.23 & $\mathrm{Rp}$ & 0.63 \\
\hline 8 & EG-513121-BL & TAP SCREW ZK TSAF 3X12 & $14.277 \%$ & $\mathrm{Rp}$ & 72 & $\mathrm{Rp}$ & 10.21 & $\mathrm{Rp}$ & 0.21 \\
\hline 9 & GN-184380-HKA00 & $\begin{array}{l}\text { STICKER HOLOGRAM WARRANTY } \\
\text { VOID }\end{array}$ & $14.277 \%$ & $\mathrm{Rp}$ & 100 & $\mathrm{Rp}$ & 14.28 & $\mathrm{Rp}$ & 0.3 \\
\hline 10 & GN-184665-HKA00 & STICKER ADD FOR CARTON PAS 59 & $14.277 \%$ & $\mathrm{Rp}$ & 375 & $\mathrm{Rp}$ & 53.54 & $\mathrm{Rp}$ & 1.1 \\
\hline
\end{tabular}


Tabel 4. Perhitungan Biaya Simpan Barang Jadi

\begin{tabular}{|c|c|c|r|rr|lr|}
\hline No & Jenis Produk & $\begin{array}{c}\text { Harga Pokok } \\
\text { Produksi }\end{array}$ & $\begin{array}{c}\text { Persentase } \\
\text { Biaya }\end{array}$ & \multicolumn{2}{c|}{$\begin{array}{c}\text { Nilai } \\
\text { Simpan/Tahun }\end{array}$} & \multicolumn{2}{c|}{$\begin{array}{c}\text { Nilai } \\
\text { Simpan/Minggu }\end{array}$} \\
\hline 1 & PS-PAS03(B) 37 & Rp 554,463 & $14.277 \%$ & $\mathrm{Rp}$ & 79,161 & $\mathrm{Rp}$ & 1,649 \\
\hline 2 & PS-PAS02(B) 27 & $\mathrm{Rp} \mathrm{459,431}$ & $14.277 \%$ & $\mathrm{Rp}$ & 65,593 & $\mathrm{Rp}$ & 1,367 \\
\hline 3 & PS-PAS09(B) 59 & $\mathrm{Rp} \mathrm{732,477}$ & $14.277 \%$ & $\mathrm{Rp}$ & 104,576 & $\mathrm{Rp}$ & 2,179 \\
\hline 4 & PS-PAS01B(B) & $\mathrm{Rp} \mathrm{256,040}$ & $14.277 \%$ & $\mathrm{Rp}$ & 36,555 & $\mathrm{Rp}$ & 762 \\
\hline 5 & PS-PAS07(B) 77 & $\mathrm{Rp} \mathrm{603,094}$ & $14.277 \%$ & $\mathrm{Rp}$ & 86,104 & $\mathrm{Rp}$ & 1,794 \\
\hline 6 & PS-PAS08(B) 68 & $\mathrm{Rp} \mathrm{555,248}$ & $14.277 \%$ & $\mathrm{Rp}$ & 79,273 & $\mathrm{Rp}$ & 1,652 \\
\hline
\end{tabular}

\subsubsection{Biaya Setup}

Pada stasiun kerja active speaker terdapat 19 stasiun kerja (19 orang) di dalam pabrik. Setiap stasiun kerja memiliki waktu setup selama 100 detik, setup dilakukan untuk mempersiapkan mesin atau alat-alat yang digunakan untuk kegiatan proses produksi.

Total upah/tahun/orang $=\operatorname{Rp} 24,533,604+\mathrm{Rp} \mathrm{2,044,467}$

$$
=\operatorname{Rp} 26,578,071
$$

$$
\begin{aligned}
\text { Upah/jam/orang } & =\frac{553,710}{40 \text { jam kerja }} \\
& =\operatorname{Rp~} 13,843 / \text { tenaga kerja/jam } \\
\text { Biaya setup } & =\frac{19 \text { stasiun kerja } \times 100 \text { detik }}{3600 \text { detik/jam }} \times 13,843 \\
& =\operatorname{Rp~} 7,306 / \text { kali setup }
\end{aligned}
$$

\subsection{Pengendalian Persediaan}

\subsubsection{Metode Saat Ini}

Bill of Material (BOM) pada produk active speaker terdiri dari 4 level. Pada tahap proses lot sizing, teknik lotting yang digunakan untuk level 0 adalah Lot For Lot dikarenakan semua produk yang diproduksi langsung dikirim ke distributor penjualan, sedangkan level 1,2,3 mirip dengan

\begin{tabular}{|c|c|c|c|c|c|c|c|c|c|c|c|c|c|}
\hline No & Row Labels & Nama Material / Komponen & Supplier & Kota & \multicolumn{2}{|c|}{ Total Biaya Pesan } & $\begin{array}{r}\text { Jumlah } \\
\text { Penyimpanan }\end{array}$ & \multicolumn{2}{|c|}{$\begin{array}{l}\text { Biaya Baha Baku } \\
\text { Simpan n }\end{array}$} & \multicolumn{2}{|c|}{$\begin{array}{l}\text { Total Biaya } \\
\text { Simpan }\end{array}$} & \multicolumn{2}{|c|}{ Total Biaya } \\
\hline 1 & BA-332102-K9 & LF CER CAP 3N3 K 1KVYB TAPING & $\mathrm{FH}$ & PURWAKARTA & $\mathrm{Rp}$ & 384,096 & 22,450 & $\mathrm{Rp}$ & 1.95 & $\mathrm{Rp}$ & $43,704.05$ & $\mathrm{Rp}$ & $427,800.05$ \\
\hline 2 & BG-106500-MVL & LF ELECT CAP 10U M50V TAPING & SUSCON & CHANGZHOU & $\mathrm{Rp}$ & 663,096 & 22,450 & $\mathrm{Rp}$ & 0.62 & $\mathrm{Rp}$ & $13,955.92$ & $\mathrm{Rp}$ & $677,051.92$ \\
\hline 3 & BH-685500-MV & LF ELECT CAP BPHF 6U8 M50V & DAEW00_V & BINH DUONG & $\mathrm{Rp}$ & $1,326,192$ & 49,900 & $\mathrm{Rp}$ & 13.33 & $\mathrm{Rp}$ & $665,298.53$ & $\mathrm{Rp}$ & $1,991,490.53$ \\
\hline 4 & EB-132000-01L & LF TERMINAL 3X3-5 T90 & GUAN_YIN & SHENGZHOU & $\mathrm{Rp}$ & 663,096 & 24,000 & $\mathrm{Rp}$ & 2.19 & $\mathrm{Rp}$ & $52,610.75$ & $\mathrm{Rp}$ & $715,706.75$ \\
\hline 5 & EB-132000-03E & TERMINAL YD200-30A-T45 & \multirow[t]{2}{*}{ TIANLE } & \multirow[t]{2}{*}{ SHENGZHOU } & \multirow[t]{2}{*}{ Rp } & \multirow[t]{2}{*}{492,096} & 109,000 & $\mathrm{Rp}$ & 2.01 & $\mathrm{Rp}$ & $219,325.95$ & \multirow[t]{2}{*}{$\mathrm{Rp}$} & \multirow[t]{2}{*}{$1,131,890.75$} \\
\hline 6 & EB-205001-312 & TERMINAL & & & & & 149,000 & $\mathrm{Rp}$ & 2.82 & $\mathrm{Rp}$ & $420,468.80$ & & \\
\hline 7 & EC-134255-DAB00 & COVER FOR WOOFER GGB (HI.438) & \multirow[t]{2}{*}{ PRESIND0 } & \multirow[t]{2}{*}{ TANGERANG } & \multirow[t]{2}{*}{ Rp } & \multirow[t]{2}{*}{384,096} & 15,000 & $\mathrm{Rp}$ & 9.68 & $\mathrm{Rp}$ & $145,223.86$ & \multirow[t]{2}{*}{$\mathrm{Rp}$} & \multirow[t]{2}{*}{$588,205.79$} \\
\hline 8 & EC-134258-DAB00 & COVER FOR MIDRANGE GGB (HI.438) & & & & & 9,000 & $\mathrm{Rp}$ & 6.54 & $\mathrm{Rp}$ & $58,885.93$ & & \\
\hline 9 & EC-134313-DAB00 & $\begin{array}{l}\text { COVER FOR BASS REFLEX GGB } \\
\text { (HI.438) }\end{array}$ & \multirow[t]{2}{*}{ ASIA_PA } & \multirow[t]{2}{*}{ KUDUS } & & \multirow[t]{2}{*}{526,644} & 9,000 & Rp & 4.97 & $\mathrm{Rp}$ & $44,711.55$ & \multirow{2}{*}{\multicolumn{2}{|c|}{$\mathrm{Rp}$}} \\
\hline 10 & EC-134681-DAA00 & REFLECTOR FOR TWEETER GGB & & & & & 22,450 & $\mathrm{Rp}$ & 2.93 & $\mathrm{Rp}$ & $65,739.71$ & & \\
\hline 241 & NK-134665-DAA00 & FRONT PANEL LH SPK GGE & YUJU_I & Cikarang Selatan & Rp & 768,192 & 25,450 & $\mathrm{Rp}$ & 39.98 & $\mathrm{Rp}$ & $1,017,530.42$ & $\mathrm{Rp}$ & $1,785,722.42$ \\
\hline & & \begin{tabular}{|c|} 
Total \\
\end{tabular} & & & $\mathrm{Rp}$ & $649,156.00$ & & & & & $31,967,889.19$ & $\mathrm{Rp}$ & $47,617,045.19$ \\
\hline
\end{tabular}
Fix Period Requirement, dimana jumlah pemesanan dilakukan setiap 4 hingga 5 minggu sekali. Sebagai contoh, rekapitulasi biaya pengendalian persediaan saat ini ditunjukkan dalam Tabel 5 .

Tabel 5. Rekapitulasi Biaya Pengendalian Persediaan Saat Ini 
Perbandingan proporsi antara biaya pesan dengan biaya simpan disajikan dalam bentuk pie chart pada Gambar 3.

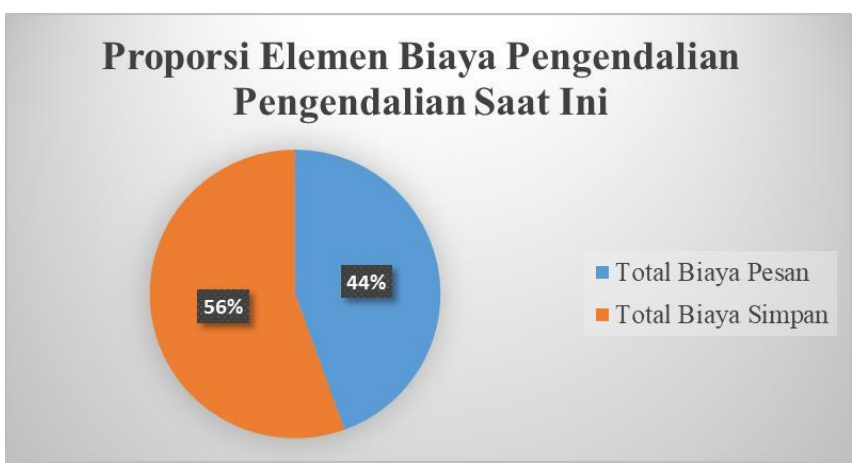

Gambar 3. Pie Chart Proporsi Elemen Biaya Pengendalian Persediaan Saat Ini

Penyebab tingginya total biaya pengendalian persediaan saat ini adalah biaya simpan dengan proporsi sebesar 56\%. Hal ini menunjukkan bahwa rata-rata jumlah barang yang disimpan di gudang berlebihan.

\subsubsection{Metode Usulan (Wagner Within)}

Perhitungan teknik lotting Wagner Whitin menggunakan konsep optimasi dalam mendapatkan pemesanan yang optimum untuk seluruh jadwal kebutuhan bersih dengan meminimasi total biaya pengadaan dan biaya simpan. Hasil perhitungan menunjukkan bahwa order quantity dalam POR untuk semua bahan baku melebihi dari minimum order quantity yang ditetapkan dari supplier. Rekapitulasi biaya pengendalian persediaan usulan ditunjukkan dalam Tabel 6.

Tabel 6. Rekapitulasi Biaya Pengendalian Persediaan Usulan

\begin{tabular}{|c|c|c|c|c|c|c|c|c|c|c|c|c|}
\hline No & Row Labels & Nama Material / Komponen & Supplier & Kota & $\begin{array}{c}\text { Frekuensi } \\
\text { Pemesanan } \\
\text { (Kali) }\end{array}$ & Biaya Pesan & \multicolumn{2}{|c|}{ Total Biaya Pesan } & \multicolumn{2}{|c|}{$\begin{array}{c}\text { Biaya Simpan Bahan } \\
\text { Baku }\end{array}$} & \multicolumn{2}{|c|}{ Total Biaya } \\
\hline 1 & BA-332102-K9 & LF CER CAP 3N3 K 1KVYB TAPING & $\mathrm{FH}$ & PURWAKARTA & 3 & Rp 64,016 & $\mathrm{Rp}$ & 192,048 & $\mathrm{Rp}$ & $138,310.66$ & $\mathrm{Rp}$ & $330,358.66$ \\
\hline 2 & BG-106500-MVL & LF ELECT CAP 10U M50V TAPING & SUSCON & CHANGZHOU & 17 & $\operatorname{Rp} 110,516$ & $\mathrm{Rp}$ & $1,878,772$ & $\mathrm{Rp}$ & $170,740.75$ & $\mathrm{Rp}$ & $2,049,512.75$ \\
\hline 3 & BH-685500-MV & LF ELECT CAP BPHF 6U8 M50V & DAEW00_V & BINH DUONG & 16 & $\operatorname{Rp} 110,516$ & $\mathrm{Rp}$ & $1,768,256$ & $\mathrm{Rp}$ & 422,646 & Rp & $2,190,902.00$ \\
\hline 4 & EB-132000-01L & LF TERMINAL 3X3-5 T90 & GUAN_YIN & SHENGZHOU & 3 & Rp 110,516 & $\mathrm{Rp}$ & 331,548 & $\mathrm{Rp}$ & 316,536 & $\mathrm{Rp}$ & $648,084.00$ \\
\hline 5 & EB-132000-03E & TERMINAL YD200-30A-T45 & \multirow[t]{2}{*}{ TIANLE } & \multirow[t]{2}{*}{ SHENGZHOU } & \multirow[t]{2}{*}{12} & \multirow[t]{2}{*}{ Rp 110,516 } & \multirow[t]{2}{*}{$\mathrm{Rp}$} & \multirow[t]{2}{*}{739,972} & $\mathrm{Rp}$ & 345,474 & \multirow[t]{2}{*}{ Rp } & \multirow[t]{2}{*}{$1,479,944$} \\
\hline 6 & EB-205001-312 & TERMINAL & & & & & & & $\mathrm{Rp}$ & 394,498 & & \\
\hline 7 & EC-134255-DAB00 & COVER FOR WOOFER GGB (HI.438) & \multirow[t]{2}{*}{ PRESIND0 } & \multirow[t]{2}{*}{ TANGERANG } & \multirow[t]{2}{*}{6} & \multirow[t]{2}{*}{ Rp 64,016 } & \multirow[t]{2}{*}{$\mathrm{Rp}$} & \multirow[t]{2}{*}{384,096} & $\mathrm{Rp}$ & 205,251 & \multirow[t]{2}{*}{ Rp } & \multirow[t]{2}{*}{638,418} \\
\hline 8 & EC-134258-DAB00 & COVER FOR MIDRANGE GGB (HI.438) & & & & & & & $\mathrm{Rp}$ & 49,071 & & \\
\hline 9 & EC-134313-DAB00 & COVER FOR BASS REFLEX GGB (HI.438) & \multirow[t]{2}{*}{ ASIA_PA } & \multirow[t]{2}{*}{ KUDUS } & \multirow[t]{2}{*}{12} & \multirow[t]{2}{*}{$\operatorname{Rp} 58,516$} & \multirow[t]{2}{*}{$\mathrm{Rp}$} & \multirow[t]{2}{*}{702,192} & $\mathrm{Rp}$ & 44,711 & \multirow[t]{2}{*}{ Rp } & \multirow[t]{2}{*}{$1,062,374$} \\
\hline 10 & EC-134681-DAA00 & REFLECTOR FOR TWEETER GGB & & & & & & & Rp & 315,471 & & \\
\hline 241 & NK-134665-DAA00 & FRONT PANEL LH SPK GGE & YUJU_I & Cikarang Selatan & 26 & Rp 64,016 & $\mathrm{Rp}$ & $1,664,416$ & Rp & 133,937 & $\mathrm{Rp}$ & $1,798,353$ \\
\hline \multicolumn{7}{|c|}{ Total } & \multicolumn{2}{|c|}{ Rp 75,138,760.00 } & \multicolumn{2}{|c|}{ Rp 35,895,121.91 } & \multicolumn{2}{|c|}{ Rp 111,033,881.91 } \\
\hline
\end{tabular}

Perbandingan proporsi antara biaya pesan dengan biaya simpan disajikan dalam bentuk pie chart pada Gambar 4.

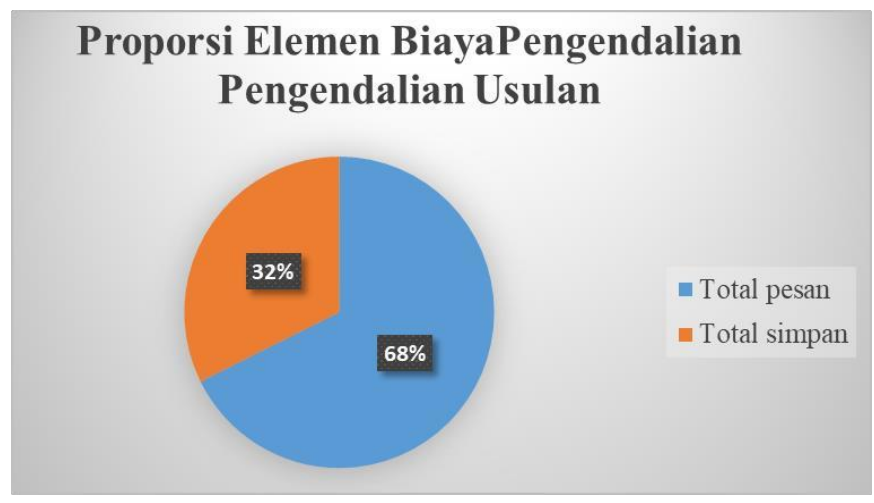

Gambar 4. Pie Chart Proporsi Elemen Biaya Pengendalian Persediaan Usulan 
Proporsi biaya simpan terhadap total biaya pengendalian persediaan metode usulan relatif lebih kecil dibandingkan dengan proposi biaya pesan (32\%). Hal ini kontradiktif dengan proporsi biaya simpan pada metode saat ini, dimana proporsi biaya simpan relatif lebih besar dibandingkan dengan biaya pesan $(56 \%)$.

\subsubsection{Perbandingan Pengendalian Persedian Metode Saat Ini dan Usulan}

Perbandingan biaya pesan antara metode saat ini dengan metode usulan ditunjukkan dalam Tabel 7.

Tabel 7. Perbandingan Biaya Pesan Metode Saat Ini dan Metode Usulan

\begin{tabular}{|c|c|c|c|c|c|c|}
\hline \multirow[t]{2}{*}{ No } & \multirow[t]{2}{*}{ Row Labels } & \multirow[t]{2}{*}{ Nama Material / Komponen } & & Saat ini & & Nagner Whitin \\
\hline & & & \multicolumn{4}{|c|}{ Biaya Pesan } \\
\hline 2 & BG-106500-MVL & LF ELECT CAP 10U M50V TAPING & $\mathrm{Rp}$ & 663,096 & $\mathrm{Rp}$ & $1,878,772$ \\
\hline 4 & EB-132000-01L & LF TERMINAL 3X3-5 T90 & $\mathrm{Rp}$ & 663,096 & $\mathrm{Rp}$ & 331,548 \\
\hline 5 & EB-132000-03E & TERMINAL YD200-30A-T45 & \multirow[t]{2}{*}{$\mathrm{Rp}$} & \multirow[t]{2}{*}{492,096} & \multirow[t]{2}{*}{$\mathrm{Rp}$} & \multirow[t]{2}{*}{739,972} \\
\hline 6 & EB-205001-312 & TERMINAL & & & & \\
\hline 8 & EC-134258-DABOO & COVER FOR MIDRANGE GGB (HI.438) & $\mathrm{Rp}$ & 384,096 & $\mathrm{Rp}$ & 384,096 \\
\hline 9 & EC-134313-DABOO & COVER FOR BASS REFLEX GGB (HI.438) & \multirow[t]{2}{*}{$\mathrm{Rp}$} & \multirow[t]{2}{*}{526,644} & \multirow[t]{2}{*}{$\mathrm{Rp}$} & \multirow[t]{2}{*}{702,192} \\
\hline 10 & EC-134681-DAAOO & REFLECTOR FOR TWEETER GGB & & & & \\
\hline 241 & NK-134665-DAA00 & FRONT PANEL LH SPK GGE & $\mathrm{Rp}$ & 768,192 & $\mathrm{Rp}$ & $1,664,416$ \\
\hline & & Total & $\mathrm{Rp}$ & $65,649,156.00$ & $\mathrm{Rp}$ & $75,138,760.00$ \\
\hline
\end{tabular}

Total biaya pesan metode usulan hampir sama dengan metode saat ini, dimana total biaya pesan usulan lebih besar dibandingkan dengan metode saat ini dengan selisih sebesar Rp 9,489,604,- atau mengalami peningkatan sebesar $14 \%$. Hal ini dikarenakan frekuensi total pemesanan bahan baku/komponen ke seluruh supplier dengan metode usulan lebih besar dibandingkan dengan metode saat ini.

Perbandingan biaya simpan antara metode saat ini dengan metode usulan ditunjukkan dalam Tabel 8.

Tabel 8. Perbandingan Biaya Simpan Metode Saat Ini dan Metode Usulan

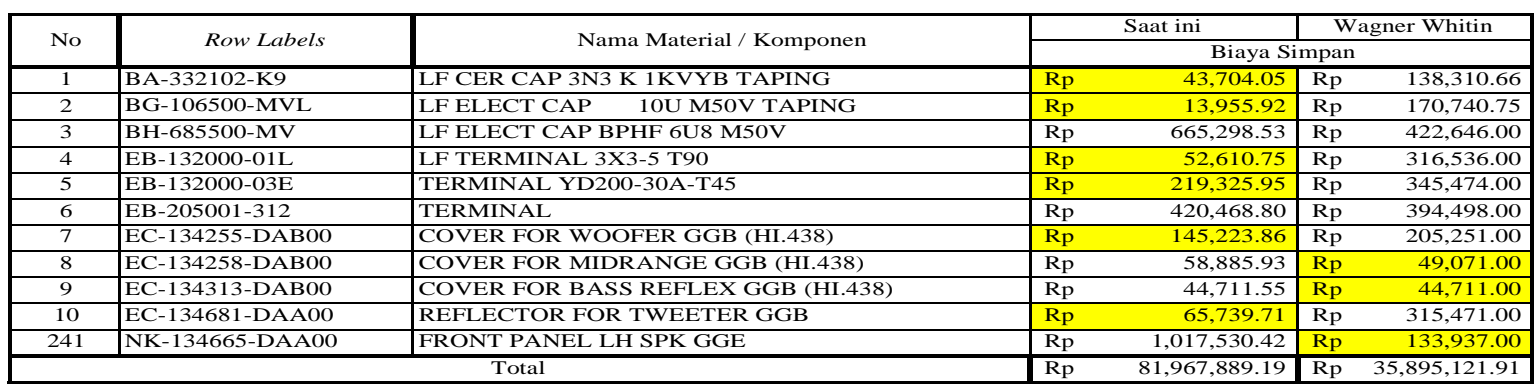

Total biaya simpan metode usulan relatif lebih kecil dibandingkan dengan metode saat ini dengan selisih sebesar Rp 46,072,767.28 atau mengalami penurunan sebesar 56\% . Penurunan biaya simpan tersebut terutama dihasilkan dari penurunan biaya simpan untuk komponen TH-047001AT, dimana penurunan biaya simpan komponen tersebut sebesar Rp 6,921,789.65 atau 15\% dari total penurunan biaya simpan yang terjadi.

Perbandingan total biaya pengendalian persediaan antara metode saat ini dengan metode usulan ditunjukkan dalam Tabel 9. 
Tabel 9. Perbandingan Total Biaya Pengendalian Persediaan antara Metode Saat Ini dan Metode Usulan

\begin{tabular}{|c|c|c|c|c|c|c|c|c|}
\hline No & Row Labels & Nama Material / Komponen & Supplier & Kota & & aat ini & \multicolumn{2}{|c|}{ Wagner Whitin } \\
\hline 2 & BG-106500-MVL & \begin{tabular}{|ll} 
LF ELECT CAP & $10 \mathrm{U}$ M50V TAPING \\
\end{tabular} & SUSCON & \begin{tabular}{|l} 
CHANGZHOU \\
\end{tabular} & $\mathrm{Rp}$ & $677,051.92$ & $\mathrm{Rp}$ & $2,049,512.75$ \\
\hline 3 & BH-685500-MV & LF ELECT CAP BPHF 6U8 M50V & DAEWOO_V & BINH DUONG & & $991,490.53$ & $\mathrm{Rp}$ & $2,190,902.00$ \\
\hline 5 & EB-132000-03E & TERMINAL YD200-30A-T45 & \multirow[b]{2}{*}{ TIANLE } & \multirow[b]{2}{*}{ SHENGZHOU } & \multirow{2}{*}{\multicolumn{2}{|c|}{ Rp 1,131,890.75 }} & \multirow[b]{2}{*}{$\mathrm{Rp}$} & \multirow[b]{2}{*}{$1,479,944.00$} \\
\hline 6 & EB-205001-312 & TERMINAL & & & & & & \\
\hline 7 & EC-134255-DAB00 & COVER FOR WOOFER GGB (HI.438) & PRESINDO & TANGERANG & $\mathrm{Rp}$ & $588,205.79$ & $\mathrm{Rp}$ & $638,418.00$ \\
\hline 10 & EC-134681-DAA00 & REFLECTOR FOR TWEETER GGB & ASIA_PA & KUDUS & $\mathrm{Rp}$ & $637,095.26$ & $\mathrm{Rp}$ & $1,062,374.00$ \\
\hline 241 & NK-134665-DAA00 & \begin{tabular}{|l|l} 
FRONT PANEL LH SPK GGE \\
\end{tabular} & YUJU_I & Cikarang Selatan & & $785,722.42$ & $\mathrm{Rp}$ & $1,798,353.00$ \\
\hline & & Total & & & $\mathrm{Rp}$ & $\overline{6}, 617,045.19$ & & $1,033,881.91$ \\
\hline
\end{tabular}

Total biaya pengendalian persediaan metode usulan relatif lebih kecil dibandingkan dengan metode saat ini dengan selisih sebesar Rp 36,583,163.28 atau mengalami penurunan sebesar $25 \%$. Penurunan total biaya pengendalian persediaan tersebut dikarenakan terjadinya penurunan biaya simpan sebesar $\mathrm{Rp}$ 46,072,767.28, walaupun biaya pesan mengalami peningkatan sebesar Rp $9,489,604$. Penurunan biaya simpan yang terjadi dikarenakan frekuensi pemesanan yang lebih besar, sehingga jumlah rata-rata barang yang disimpan lebih sedikit.

Penjadwalan pemesanan bahan baku pada PT HIT menggunakan teknik lotting Wagner Within dihasilkan biaya persediaan material yang tinggi, frekuensi pemesanan yang berbeda mempengaruhi jumlah inventori yang disimpan sehingga akan berpengaruh pada biaya pesan dan simpan yang dikeluarkan oleh perusahaan. Pada kondisi saat ini, perusahaan melakukan pemesanan setiap kali adanya produksi yang akan dilakukan adalah 4 hingga sampai 5 minggu sekali. Sedangkan dengan menggunakan teknik lotting Wagner Within, pemesanan yang dilakukan bervariasi (baik frekuensi maupun interval pemesanan) sesuai dengan perhitungan algoritma yang dilakukan. Total biaya simpan yang dimiliki oleh teknik lotting Wagner Within lebih kecil dibandingkan dengan teknik yang digunakan oleh perusahaan dimana setiap pesanan yang dilakukan dapat memenuhi kebutuhan dalam beberapa periode kedepan sehingga jumlah bahan baku yang disimpan digudang akan langsung digunakan pada periode berikutnya. Pada kondisi saat ini, seringkali pemesanan bahan baku tidak melihat keadaan kedatangan jumlah bahan baku saat dipesan dan yang telah ada di gudang untuk proses produksi maka rata-rata penyimpanan bahan baku digudang cukup banyak.

\section{Kesimpulan dan Saran}

Berdasarkan hasil pengolahan data dan analisis yang dilakukan, dapat ditarik kesimpulan sebagai berikut:

1. Kekurangan pengendalian persediaan yang diterapkan perusahaan saat ini adalah terjadinya penumpukan bahan baku di gudang . hal ini menimbulkan tingginya biaya simpan yang timbul, yaitu sebesar Rp 81,967,889.19 atau 56\% dari total biaya pengendalian persediaan yang timbul.

2. Pengendalian persediaan yang sebaiknya diterapkan perusahaan adalah metode MRP dengan teknik lotting Wagner Whitin.

3. Manfaat penerapan pengendalian persediaan usulan adalah diperolehnya penghematan total biaya pengendalian persediaan sebesar Rp 36,583163.28 atau 25\% dibandingkan total biaya pengendalian persediaan saat ini.

Beberapa hal yang disarankan kepada perusahaan terkait dengan perubahan teknik lotting usulan sebagai berikut:

1. Perusahaan sebaiknya mengadakan sosialisasi mengenai perubahan teknik lotting dalam melakukan perencanaan kebutuhan bahan baku kepada Bagian PPIC.

2. Perusahaan sebaiknya menerapkan teknik lotting usulan untuk mengendalikan persediaan produk active speaker untuk tipe lainnya. 
JOURNAL OF INTEGRATED SYSTEM VOL 3. NO. 1, JUNI 2020: 59-71

\section{Daftar Pustaka}

Baroto, Teguh, (2002), Perencanaan dan Pengendalian Produksi, Ghalia Indonesia.

Fogarty, (1991), Production and Inventory Management, South Western Pub. Co, $2^{\text {nd }}$ ed.

Kusuma, Hendra, (2001), Perencanaan dan Pengendalian Produksi, Andi Yogyakarta.

Nur Bahagia, Senator, (2006), Sistem Inventori, ITB.

Rangkuti, Freddy, (2004), Manajemen Persediaan, Rajawali PERS.

Ristono, Agus, (2009), Manajemen Persediaan, Graha Ilmu.

Rusdiana, M.M., (2014), Manajemen Operasi, Pustaka, Bandung.

Santoso dan Heryanto, Rainisa, (2017), Perencanaan dan Pengendalian Produksi 1, Alfabeta. Bandung.

Sheikh, Khalid, (2002), Manufacturing Resource Planning (MRP II), Mc Graw Hill.

Tersine, Richard J., (1994), Principle of Inventory and Material Management, Fourth Edition., Prentice Hall. 